\title{
Spatial Dissemination of Some Heavy Metals in Soil Adjacent to Bhaluka Industrial Area, Mymensingh, Bangladesh
}

\author{
Abdullah Al Zabir ${ }^{1}$, M. Wahid U. Zzaman ${ }^{2}$, Md. Zakir Hossen², Md. Nizam Uddin ${ }^{1}$, \\ Md. Shariful Islam, " , Md. Saiful Islam ${ }^{3}$ \\ ${ }^{1}$ Department of Agricultural Chemistry, Patuakhali Science and Technology University, Dumki, Patuakhali, Bangladesh \\ ${ }^{2}$ Department of Agricultural Chemistry, Bangladesh Agricultural University, Mymensingh, Bangladesh \\ ${ }^{3}$ Department of Soil Science, Patuakhali Science and Technology University, Dumki, Patuakhali, Bangladesh
}

\section{Email address:}

alzabir361@gmail.com (A. A. Zabir),mzamanacm@gmail.com (M. W. U. Zzaman), zakirhm.ac.bau@gmail.com (Md. Z. Hossen), mnizamacm@yahoo.com (Md. N. Uddin), sharifulpstu@yahoo.com (Md. S. Islam), islam-md.saiful-nj@ynu.jp (Md. S. Islam)

${ }^{*}$ Corresponding author

\section{To cite this article:}

Abdullah Al Zabi, M. Wahid U. Zzaman, Md. Zakir Hossen, Md. Nizam Uddin, Md. Shariful Islam, Md. Saiful Islam. Spatial Dissemination of Some Heavy Metals in Soil Adjacent to Bhaluka Industrial Area, Mymensingh, Bangladesh. American Journal of Applied Scientific Research. Vol. 2, No. 6, 2016, pp. 38-47. doi: 10.11648/j.ajasr.20160206.12

Received: August 27, 2016; Accepted: October 26, 2016; Published: November 21, 2016

\begin{abstract}
Heavy metals released from industries causes severe environmental pollution in developing countries. This study has been conducted to evaluate the intensity of heavy metals pollution in soil at 0,30 and $60 \mathrm{~m}$ distances from waste carrying canal of Bhaluka industrial area of Mymensingh, Bangladesh. Lead (Pb), chromium $(\mathrm{Cr})$, copper $(\mathrm{Cu})$, zinc $(\mathrm{Zn})$, iron $(\mathrm{Fe})$ and manganese $(\mathrm{Mn})$ concentrations in soils decreased gradually with the increase of distance from waste canal. Maximum concentration was found at 60 to $0 \mathrm{~m}$ distance varied from 67.13-90.93, 52.23-76.73, 32.75-133.85, 61.18-422.10, 2690036900 and $240-540 \mu \mathrm{g} \mathrm{g}^{-1}$ for $\mathrm{Pb}, \mathrm{Cr}, \mathrm{Cu}, \mathrm{Zn}, \mathrm{Fe}$ and $\mathrm{Mn}$, respectively. Geoaccumulation index showing that the soil was moderately polluted for $\mathrm{Pb}$ and $\mathrm{Zn}$. Pollution load index values $>1.0$, explaining pollution load was increased adjacent to industrial area and deteriorate the quality of surface soils day by day. Contamination factor for $\mathrm{Pb}, \mathrm{Cu}$ and $\mathrm{Zn}$ were very high indicating these metals as the major soil pollutants came from anthropogenic sources which was supported by enrichment factor values $(>5)$. The extent of pollution in adjacent to this industrial area implies the condition becoming worse and alarming for biota and inhabitants of that area.
\end{abstract}

Keywords: Heavy Metal, Soil Pollution, Geoaccumulation, Pollution Load Index, Enrichment Factor

\section{Introduction}

Soil is a dynamic natural resource for the survival of human life and regarded as the key receiver of the persistent pollutants like heavy metals $[1,2]$. Therefore, soil pollution by heavy metals is a global problem due to its significant deleterious consequences on plants, animal and human health. There are numerous human activities which results in the releases of toxic materials to the soil. Bhaluka is a newly industrial growing site of Mymensingh, Bangladesh, which is highly susceptible to environmental pollution over last decade. Almost all industrial units are discharging their untreated wastes in the surface drains and spread over agricultural fields. The national pollution profile of DOE [3] showed that Bangladesh had over 30,000 industrial units of which 24,000 were small and cottage, the remaining 6,000 were large and medium industries. About 300 industries including textile, dyeing, plastics, metal fabrications, diesel plant, leather, tanning discharge wastes and effluent containing As, $\mathrm{Zn}, \mathrm{Cr}, \mathrm{Cd}, \mathrm{Pb}, \mathrm{Sr}, \mathrm{Ni}, \mathrm{Li}, \mathrm{Ag}, \mathrm{Hg}, \mathrm{Co}$ and $\mathrm{Se}$ $[2,4]$. Tanneries of Hazaribagh produce 7.7 million liters of liquid waste and 88 million tons of solid waste every day 
and about $50 \%$ is hazardous due to high heavy metal contents [5]. The industrial hot-spots of Bangladesh are located near the urban and suburban areas and most cases surrounded by agricultural fields. The irrigation of industrial, municipal, sewage-sludge effluent and dumping of solid wastes on crop fields due to its high organic matter and nutrient content is a common scenario [6]. As a result the untreated effluents get dispersed throughout the crop field and plants are exposed to a pool of toxic metals. Moreover, flooding causes inundation of the cultivated fields with industrial effluents. In rainy season, surface runoff and seepage contribute to the transport of heavy metals over distance along with waste disposals. The residence time of heavy metals in soil is of the order of thousands of years. The persistence of these metals in soils, uptake by crops results an accumulative effects in animal and human. This is because unlike organic pollutants, metals are not degraded biologically but transformed from one state to another [2, 7]. The transport and accumulation of toxic heavy metals increases the concentration in soil and vegetation. Heavy metals dispersion increases due to sewage water irrigation in soils by 2 to $80 \%$ and in crops by 14 to $209 \%$ [8]. Certain plants can accumulate heavy metals in their tissues and uptake increases generally in plants that are grown in areas with increased soil contamination with heavy metals and therefore, many people are at risk of adverse health effects from consuming common garden vegetables cultivated in contaminated soil [6]. Concern over the environmental pollutants particularly the toxic heavy metals has increased immensely in Bangladesh during the last few decades due to population explosion, unplanned industrialization and urbanization [9]. The untreated wastes and effluents from the industries are discharged randomly to soils, canals and in the vicinity of the industrial areas. Moreover, the polluted water is irrigated to paddy and vegetable fields. The study area also suffers from flooding during rainy season. In order to delineate the scope of the environmental contamination by heavy metals an ecological risk was assessed. To best of our knowledge, no systematic investigation has been conducted so far, and metal toxicity data is severely insufficient to assess the ecological risk of heavy metals in soil near the industrial area in Bangladesh. Therefore, the objectives of the present study were to investigate the spatial distribution of heavy metals in soil and to assess the level of heavy metals pollution at different distances from waste carrying canals of Bhaluka Upazilla.

Table 1. Information regarding soil sampling sites at Bhaluka, Mymensingh, Bangladesh.

\begin{tabular}{lllll}
\hline $\begin{array}{l}\text { Sampling } \\
\text { sites }\end{array}$ & Location & $\begin{array}{l}\text { Sample } \\
\text { ID }\end{array}$ & $\begin{array}{l}\text { Distance } \\
\text { from canal }\end{array}$ & $\begin{array}{l}\text { Possible sources of } \\
\text { contamination }\end{array}$ \\
\hline Site-1 & Hawaile & 1b & $0 \mathrm{~m}$ & $\begin{array}{l}\text { Glass, metallurgical, } \\
\text { textile, composite, } \\
\text { garments industry. }\end{array}$ \\
Site-2 & Hawaile & 2a & $0 \mathrm{~m}$ & Metallurgical, \\
\hline
\end{tabular}

\begin{tabular}{|c|c|c|c|c|}
\hline $\begin{array}{l}\text { Sampling } \\
\text { sites }\end{array}$ & Location & $\begin{array}{l}\text { Sample } \\
\text { ID }\end{array}$ & $\begin{array}{l}\text { Distance } \\
\text { from canal }\end{array}$ & $\begin{array}{l}\text { Possible sources of } \\
\text { contamination }\end{array}$ \\
\hline \multirow{5}{*}{ Site-3 } & \multirow{5}{*}{ Jamirdia } & $2 b$ & $30 \mathrm{~m}$ & \multirow[t]{2}{*}{$\begin{array}{l}\text { Pharmaceuticals, textile } \\
\text { and ceramic industry. }\end{array}$} \\
\hline & & $2 \mathrm{c}$ & $60 \mathrm{~m}$ & \\
\hline & & $3 a$ & $0 \mathrm{~m}$ & \multirow{3}{*}{$\begin{array}{l}\text { Textile, composite, } \\
\text { battery acid disposal, } \\
\text { electric industry. }\end{array}$} \\
\hline & & $3 b$ & $30 \mathrm{~m}$ & \\
\hline & & $3 \mathrm{c}$ & $60 \mathrm{~m}$ & \\
\hline \multirow{3}{*}{ Site-4 } & \multirow{3}{*}{ Jamirdia } & $4 a$ & $0 \mathrm{~m}$ & \multirow{3}{*}{$\begin{array}{l}\text { Electric, textile, } \\
\text { composite industry. }\end{array}$} \\
\hline & & $4 b$ & $30 \mathrm{~m}$ & \\
\hline & & $4 c$ & $60 \mathrm{~m}$ & \\
\hline \multirow{3}{*}{ Site-5 } & \multirow{3}{*}{ Amtoli } & $5 \mathrm{a}$ & $0 \mathrm{~m}$ & \multirow{3}{*}{$\begin{array}{l}\text { Ceramic, textile, } \\
\text { composite and dyeing } \\
\text { industry. }\end{array}$} \\
\hline & & $5 b$ & $30 \mathrm{~m}$ & \\
\hline & & $5 c$ & $60 \mathrm{~m}$ & \\
\hline \multirow{3}{*}{ Site- 6} & \multirow{3}{*}{ Amtoli } & $6 a$ & $0 \mathrm{~m}$ & \multirow{3}{*}{$\begin{array}{l}\text { Dyeing, composite } \\
\text { industry. }\end{array}$} \\
\hline & & $6 \mathrm{~b}$ & $30 \mathrm{~m}$ & \\
\hline & & $6 c$ & $60 \mathrm{~m}$ & \\
\hline \multirow{3}{*}{ Site-7 } & \multirow{3}{*}{ Kharuali } & $7 \mathrm{a}$ & $0 \mathrm{~m}$ & \multirow{3}{*}{$\begin{array}{l}\text { Pharmaceuticals, } \\
\text { composite, textile, } \\
\text { dyeing industry. }\end{array}$} \\
\hline & & $7 b$ & $30 \mathrm{~m}$ & \\
\hline & & $7 \mathrm{c}$ & $60 \mathrm{~m}$ & \\
\hline \multirow{3}{*}{ Site- 8} & \multirow{3}{*}{ Kharuali } & $8 \mathrm{a}$ & $0 \mathrm{~m}$ & \multirow{3}{*}{$\begin{array}{l}\text { Pharmaceuticals, } \\
\text { composite, textile and } \\
\text { dyeing industry. }\end{array}$} \\
\hline & & $8 \mathrm{~b}$ & $30 \mathrm{~m}$ & \\
\hline & & $8 \mathrm{c}$ & $60 \mathrm{~m}$ & \\
\hline \multirow{3}{*}{ Site-9 } & \multirow{3}{*}{ Bagrapara } & $9 \mathrm{a}$ & $0 \mathrm{~m}$ & \multirow{3}{*}{ Saline, dyeing industry. } \\
\hline & & $9 \mathrm{~b}$ & $30 \mathrm{~m}$ & \\
\hline & & $9 \mathrm{c}$ & $60 \mathrm{~m}$ & \\
\hline \multirow{3}{*}{ Site-10 } & \multirow{3}{*}{ Bagrapara } & $10 \mathrm{a}$ & $0 \mathrm{~m}$ & \multirow{3}{*}{$\begin{array}{l}\text { Glass, dyeing, } \\
\text { agrochemical and } \\
\text { detergent industry }\end{array}$} \\
\hline & & $10 \mathrm{~b}$ & $30 \mathrm{~m}$ & \\
\hline & & $10 \mathrm{c}$ & $60 \mathrm{~m}$ & \\
\hline
\end{tabular}

\section{Materials and Methods}

\subsection{Sampling Procedure, Preparation and Preservation}

Surface $(0-15 \mathrm{~cm})$ soil samples were collected from ten (10) sites (Table 1) near the industrial waste carrying canals to provide satisfactory representation of the entire study area of Bhaluka Upazila (Fig. 1) during February to March, 2014. Samples were collected with the help of a hand auger (a stainless steel crew) at 0,30 and $60 \mathrm{~m}$ distances from the waste discharging canals at each site (Table 1) and were kept in a clean polyethylene bags with proper labeling to avoid contamination. Then the soils were carried to the laboratory for processing and chemical analysis. Samples were placed on brown paper and air dried for two weeks and all clods were disintegrated; crumbs, stones, grabbles, plant parts, inert materials, etc. were removed and mixed uniformly. Soils were sieved through a $2-\mathrm{mm}$ sieve to remove coarse particles. The final samples were kept in labeled polypropylene containers and preserved in desiccators at room temperature for chemical analysis $[10,11]$. 


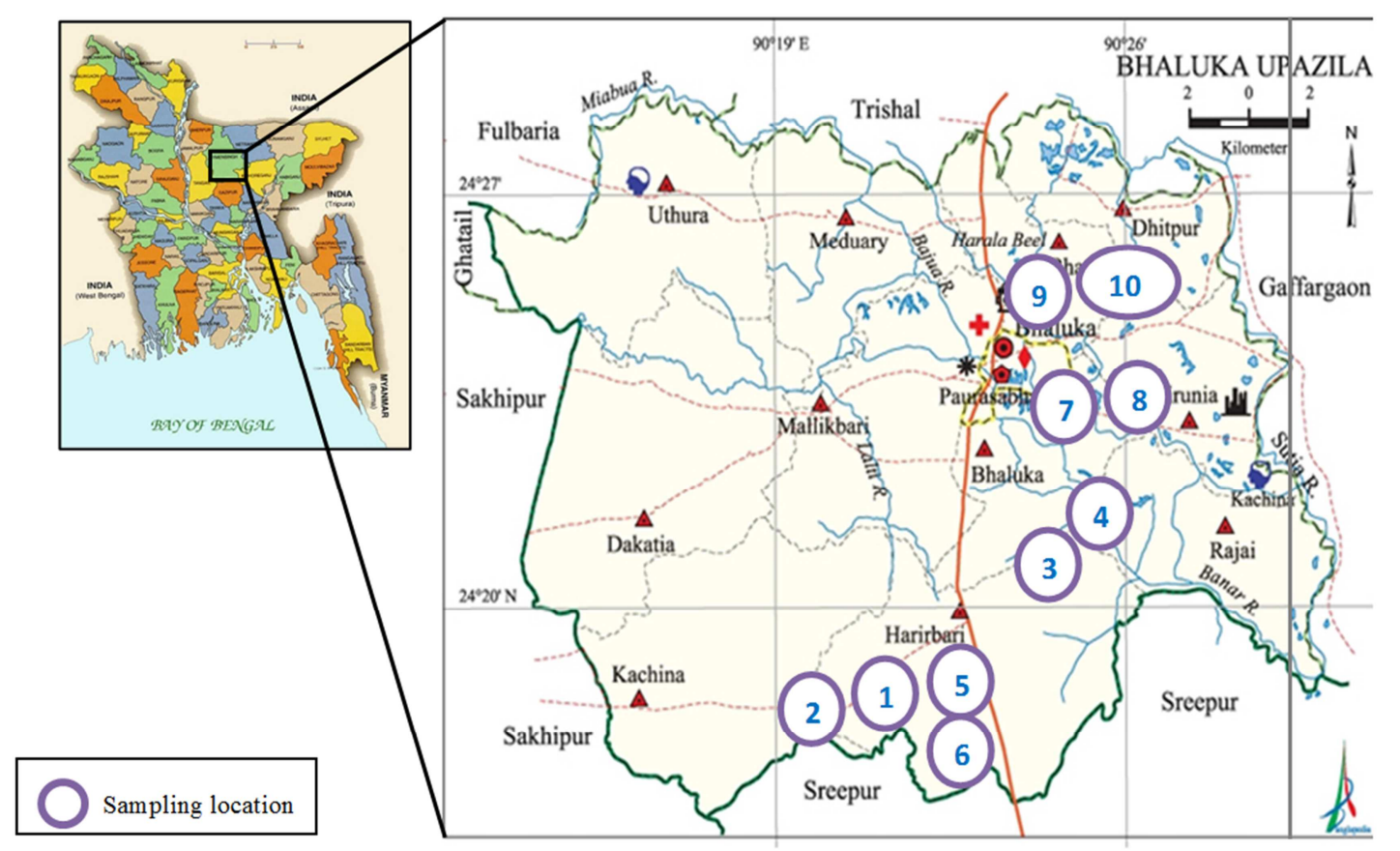

Fig. 1. Map of Bhaluka, Mymensingh, Bangladesh showing the sampling sites.

\subsection{Chemical Analysis}

Exactly $1.0 \mathrm{~g}$ soil from each sample was taken separately in $250 \mathrm{~mL}$ digestion tubes, then $10 \mathrm{~mL}$ concentrated $\mathrm{HNO}_{3}$ was added to it. The content was kept for 16 hours at room temperature for pre digestion and then heated at $140^{\circ} \mathrm{C}$ for 150 minutes [12]. Heavy metals like $\mathrm{Pb}, \mathrm{Cr}, \mathrm{Cd}, \mathrm{Cu}, \mathrm{Zn}, \mathrm{Fe}$ and $\mathrm{Mn}$ in soil sample was determined by using an atomic absorption spectrophotometer (AAS) (Model: SHIMADZU AA-7000) following method described by Sparks [13] and Singh et al. [14]. All chemicals used here were of analytical grade.

\subsection{Geoaccumulation Index $\left(I_{\text {geo }}\right)$}

A geoaccumulation indexing $\left(I_{\text {geo }}\right)$ approach was used to quantify the degree of anthropogenic contamination, and to compare the different metals in soils [15]. This quantitative check of metal pollution in soils was proposed in the form of an equation defined as the index of geoaccumulation as follows:

$$
I_{\text {geo }}=\log \left[C_{n} / 1.5 B_{n}\right]
$$

Where, $C_{n}$ is measured concentration of trace metal in the soil, and $B_{n}$ is the geochemical background for the same element which is either directly measured in pre-civilization sediments of the area or taken from the literature (average shale value as described by Turekian and Wedepohl [16]). The factor 1.5 is introduced to include possible variations of the background values that are due to lithologic variations.

\subsection{Pollution Load Index (PLI)}

Pollution load index (PLI) is a multi-metal approach, which has been introduced by Tomlinson et al. [17] for an overall assessment of soil and sediment quality with respect to trace metal concentrations. According to Tomlinson et al. [17], PLI describes the quality of a site or an estuary in terms of easily understood by the non-specialist and which can be used to compare the pollution status of different sites and estuaries. The PLI for a single site is the $n^{\text {th }}$ root of $n$ number of multiplied together contamination factor $(\mathrm{CF})$ values. The $\mathrm{CF}$ and PLI for a single site can be obtained as follows:

$$
\begin{gathered}
\mathrm{CF}=\mathrm{C}_{\text {Metal }} / \mathrm{C}_{\text {Background }} \\
P L I=\left(C F_{1} \times C F_{2} \times C F_{3} \times \ldots . . \times C F_{n}\right)^{1 / n}
\end{gathered}
$$

While computing the contamination factor (CF) for pollution load index (PLI) of soils of the studied region, average shale value for each heavy metal as described by Turekian and Wedepohl [16] were considered as background concentration values. The concept of a baseline is a fundamental issue to the formation of a PLI $[17,18]$.

\subsection{Enrichment Factor (EFc)}

To evaluate the magnitude of contaminants in the environment, the enrichment factors were computed relative to the abundance of species in source material to that found in the Earth's crust [19, 20,21]. The following equation was used to calculate the EFc-

$$
\mathrm{EFc}=\left(\mathrm{C}_{\mathrm{M}} / \mathrm{C}_{\mathrm{Fe}}\right)_{\text {sample }} /\left(\mathrm{C}_{\mathrm{M}} / \mathrm{C}_{\mathrm{Fe}}\right)_{\text {Earth's crust }}
$$

Where, $\left(\mathrm{C}_{\mathrm{M}} / \mathrm{C}_{\mathrm{Fe}}\right)_{\text {sample }}$ is the ratio of concentration of metal $\left(\mathrm{C}_{\mathrm{M}}\right)$ to that of $\mathrm{Fe}\left(\mathrm{C}_{\mathrm{Fe}}\right)$ in the soil sample, and $\left(\mathrm{C}_{\mathrm{M}} / \mathrm{C}_{\mathrm{Fe}}\right)_{\text {Earth's }}$ crust is the same reference ratio in the Earth's crust. The average abundance of metals in the reference Earth's crust was taken 
from Huheey [19] and Fe was selected as the reference element, due to its crustal dominance and its high immobility.

\subsection{Statistical Analysis}

The statistical analyses of the analytical results obtained from the chemical analysis of different soil samples were performed using Excel Statistics version 4.0 and mean differences were made by multiple $t$-test.

\section{Results and Discussion}

\subsection{Sequence of Heavy Metals in Soils}

Sequence of toxic elements in soil samples was shown in order to know the distribution of the metals in the study area. Soil heavy metals were found in the following order: $\mathrm{Fe}>\mathrm{Mn}>$ $\mathrm{Zn}>\mathrm{Cu}>\mathrm{Pb}>\mathrm{Cr}>\mathrm{Cd}$ at $0 \mathrm{~m}$ and $\mathrm{Fe}>\mathrm{Mn}>\mathrm{Zn}>\mathrm{Pb}>\mathrm{Cr}>\mathrm{Cu}>$ $\mathrm{Cd}$ at 30 and $60 \mathrm{~m}$ away from the waste canal (Fig. 2). For every metal, the highest concentration occurred in soils at the edge of waste canal. Moreover, the concentration of all heavy metals decreased with the increasing of sampling distance from waste canal. The present result agrees with the investigation made by Sultana et al. [22] who investigated the heavy metal contamination in the river sediments near industrial area of Dhaka. She found that heavy metals among all the samples were distributed in a decreasing sequence of $\mathrm{Fe}>\mathrm{Mn}>\mathrm{Zn}>\mathrm{Ni}>\mathrm{Cu}>\mathrm{Cr}>\mathrm{As}>\mathrm{Pb}>\mathrm{Cd}$.

\subsubsection{Lead, Chromium and Cadmium Concentration in Soil}

The status of $\mathrm{Pb}$ in soil samples collected at $0 \mathrm{~m}$ distance from the canal ranged between 50.72 to $90.93 \mu \mathrm{g} \mathrm{g}^{-1}$ (Fig. 2a), having an average value of $66.31 \mu \mathrm{g} \mathrm{g}^{-1}$ (Table 2). At 30 and $60 \mathrm{~m}$ distances from waste canal the concentration (range value) was $46.62-80.26$ and $40.06-67.13 \mu \mathrm{g} \mathrm{g}^{-1}$, respectively. Maximum content of $\mathrm{Pb}$ was found at Jamirdia which might be attributed due to the effects from textile, composite industry and battery acid disposal at this site $[2,6]$. All of the 10 samples at $0 \mathrm{~m}, 7$ at $30 \mathrm{~m}$ and 5 at $60 \mathrm{~m}$ distance from waste canal were contained $\mathrm{Pb}$ higher than maximum acceptable concentration $\left(50 \mu \mathrm{g} \mathrm{g}^{-1}\right)$ for crop production [23] which may result in reduced crop production and food chain contamination by exceeding concentration of $\mathrm{Pb}$. The present study results were almost thrice than other reports published earlier for soils of Bangladesh. Naser et al. [24] observed that mean concentrations of $\mathrm{Pb}$ were 20.8, 18.6 and $16.7 \mu \mathrm{g} \mathrm{g}^{-1}$ at 0 , 50 and $100 \mathrm{~m}$ distances, respectively from the highway of Gazipur, Bangladesh. Again, Bhaluka soils contained much lower $\mathrm{Pb}$ than Dashkasan gold mine soils $\left(2710 \mu \mathrm{g} \mathrm{g}^{-1}\right)$ of Iran [25]. Ahmed et al. [26] reported that $\mathrm{Pb}$ concentration of the soil of Bhaluka Upazila ranged from $12.00-34.00 \mu \mathrm{g} \mathrm{g}^{-1}$. This means $\mathrm{Pb}$ content in Bhaluka soil has been increased significantly during last decade. The total concentration of $\mathrm{Cr}$ in soil samples collected at $0 \mathrm{~m}$ distance from waste canal ranged between 35.69 to $76.73 \mu \mathrm{g} \mathrm{g}^{-1}$ (Fig. 2b), having an average value of $57.48 \mu \mathrm{g} \mathrm{g}^{-1}$ (Table 2). At 30 and $60 \mathrm{~m}$ distances from waste canal the concentration of $\mathrm{Cr}$ ranged between 26.47 to 60.51 and 25.52 to $52.23 \mu \mathrm{g} \mathrm{g}^{-1}$, respectively.
About $50 \%$ sites at both 0 and $60 \mathrm{~m}$ and $80 \%$ at $30 \mathrm{~m}$ distance showed values greater than the mean. It is certain that, soils of Bhaluka may exceed reference values of $\mathrm{Cr}$ as proposed in [16] within a short period, if present situation continues. Addo et al. [27] observed that the mean $\mathrm{Pb}, \mathrm{Cr}, \mathrm{Cu}, \mathrm{Mn}$ and $\mathrm{Zn}$ concentrations in the soils decreased as distance increased from the Diamond Cement Factory, Aflao, Ghana. This indicated that the factory which is the only industrial source in the area is the major cause of the pollutants contamination in its vicinity. The study conducted by Ahmed et al. [28] at two Municipal Solid Wastes (MSW) dumpsites at Alexandria in Egypt also showed the similar trend of heavy metal contamination in soils. All the soil samples collected from Bhaluka Upazilla contained trace amount of Cd $(<0.0001 \mu \mathrm{g}$ $\left.\mathrm{g}^{-1}\right)$. This indicates that industrial effluents of this area did not contain considerable amount of $\mathrm{Cd}$ and this area is not yet susceptible to Cd pollution.

\subsubsection{Copper, Zinc, Iron and Manganese Concentration in Soil}

Total concentration of $\mathrm{Cu}$ in soils at 0,30 and $60 \mathrm{~m}$ distances from industrial waste flowing canal ranged between

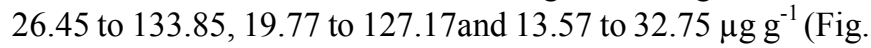
$2 \mathrm{c}, 2 \mathrm{~d}, 2 \mathrm{e}, 2 \mathrm{f}$ ) having an average value of $77.85,45.24$ and $24.23 \mu \mathrm{g} \mathrm{g}^{-1}$, respectively (Table 2). Out of 10 sites, 6 at $0 \mathrm{~m}, 2$ at $30 \mathrm{~m}$ and 5 at $60 \mathrm{~m}$ away from canal had values more than the mean. The highest concentration was observed at Jamirdia (site-4). Electric industries used huge amount of $\mathrm{Cu}$ which might have given rise to greater $\mathrm{Cu}$ concentration at Jamirdia. The amount of $\mathrm{Cu}$ was quite greater than that $\left(3.8 \mu \mathrm{g} \mathrm{g}^{-1}\right)$ observed by Al-Oud et al. [29] who studied the heavy metal content of soil around a cement factory in Riyadh city, Central Saudi Arabia. An elevated level of $\mathrm{Cu}$ was also observed by Islam et al. [6], where $\mathrm{Cu}$ concentration in soils of vegetables field around Dhaka City, Bangladesh was $311 \mu \mathrm{g} \mathrm{g}^{-1}$ (mean value). The mean concentration of $\mathrm{Cu}$ in most of the soil samples at the closest point to the waste canal was almost thrice of the toxicity reference value as reported in [30]. Total amount of $\mathrm{Zn}$ in soils at $0 \mathrm{~m}$ distance from waste canal of Bhaluka ranged between 81.75 to 422.10 (Fig. 2d), having an average value of $245.12 \mu \mathrm{g} \mathrm{g}^{-1}$ (Table 2). The concentration at 30 and $60 \mathrm{~m}$ distances ranged between 40.53 to 132.60 and 33.06 to $61.18 \mu \mathrm{g} \mathrm{g}^{-1}$ with an average value of 74.16 and 50.32 $\mu \mathrm{g} \mathrm{g}^{-1}$, respectively. Zn concentration was observed maximum at Kharuali (site-7). The pharmaceuticals are presumed to raise $\mathrm{Zn}$ content at Kharuali. Four samples at $0 \mathrm{~m}, 2$ at $30 \mathrm{~m}$ and 5 at $60 \mathrm{~m}$ distance had values greater than the mean. The mean concentration of $\mathrm{Zn}\left(245.12 \mu \mathrm{g} \mathrm{g}^{-1}\right)$ at $0 \mathrm{~m}$ distance from waste canal was much greater than both the normal range (35.0-129.0 $\mu \mathrm{g} \mathrm{g}^{-1}$ ) at Bhaluka Upazila [26] and average shale value $\left(95 \mu \mathrm{g} \mathrm{g}^{-1}\right)$ [16]. Total $\mathrm{Fe}$ content in soils at the edge of waste canal ranged from 23900 to 36900 (Fig. 2e) having a mean value of $27980 \mu \mathrm{g} \mathrm{g}^{-1}$ (Table 2). The range of Fe at $30 \mathrm{~m}$ distance from waste canal was 18000 to $33000 \mu \mathrm{g} \mathrm{g}^{-1}$ and the mean value was $24230 \mu \mathrm{g} \mathrm{g}^{-1}$. At $60 \mathrm{~m}$, Fe occurred in the range of 17400 to 26900 with a mean value of $21840 \mu \mathrm{g} \mathrm{g}^{-1} .50$, 60 and $70 \%$ sites at 0,30 and $60 \mathrm{~m}$ distances, respectively 
showed values greater than the mean. The study revealed similar results with that of Sakawi et al. [31] who found $\mathrm{Fe}$ as the most dominant per specific distances and depths and exceeded the DOE minimum standard $\left(301 \mu \mathrm{g} \mathrm{g}^{-1}\right)$ around the Vicinity of open landfill of Malaysia. The highest level of Fe was observed at site-2 (Hawaile) while lowest was seen at site-8 (Kharuali) and site-9 (Bagrapara). Effluents from metallurgical industry at Hawaile might contain higher amount of $\mathrm{Fe}$ to increase soil Fe concentration. According to Allaway [32], typical uncontaminated soil contains 7000 $55000 \mu \mathrm{g} \mathrm{g}^{-1} \mathrm{Fe}$. Total $\mathrm{Mn}$ in soils at 0,30 and $60 \mathrm{~m}$ distances from industrial waste flowing canal ranged between 160 to
540, 90 to 250 and 80 to $240 \mu \mathrm{g} \mathrm{g}^{-1}$ (Fig. 2f) having an average value of 264,158 and $125 \mu \mathrm{g} \mathrm{g}^{-1}$, respectively (Table 2). Out of 10 samples, 4 at $0 \mathrm{~m}, 2$ at $30 \mathrm{~m}$ and 3 at $60 \mathrm{~m}$ distance had values greater than the mean. Maximum and minimum content of Mn was seen at Hawaile (site-1) and Kharuali (site-8), respectively. The concentration of Mn was higher compared to the industrial area of west Algeria where the concentration of $\mathrm{Mn}$ in soil of 3 regions was 244.94, 92.00 and $79.03 \mu \mathrm{g} \mathrm{g}^{-1}$ [33]. The heavy metal pollution indicates that leachate produced by uncontrolled and unscientific disposal of industrial untreated wastes contaminates soil samples of the industrial area [34].

Table 2. Mean $\mathrm{Pb}, \mathrm{Cr}, \mathrm{Cu}, \mathrm{Zn}, \mathrm{Fe}$ and Mn concentration in $\mu \mathrm{g} \mathrm{g}^{-1}$ ( \pm standard deviation) of soils at 0,30 and $60 \mathrm{~m}$ away from waste canal.

\begin{tabular}{lllllll}
\hline Distance from waste canal & \multicolumn{5}{l}{ Heavy metals $\left(\boldsymbol{\mu g} \mathbf{g}^{-1}\right)$} \\
\hline waste canal & $\mathrm{Pb}$ & $\mathrm{Cr}$ & $\mathrm{Cu}$ & $\mathrm{Zn}$ & $\mathrm{Fe}$ & $\mathrm{Mn}$ \\
\hline $0 \mathrm{~m}$ & $66.31 \pm 14.32 \mathrm{a}$ & $57.48 \pm 13.09 \mathrm{~b}$ & $77.84 \pm 40.68 \mathrm{~b}$ & $245.11 \pm 135.20 \mathrm{~b}$ & $27980 \pm 3738.92 \mathrm{~b}$ & $264 \pm 112.96 \mathrm{~b}$ \\
$30 \mathrm{~m}$ & $59.26 \pm 12.73 \mathrm{a}$ & $48.35 \pm 10.53 \mathrm{ab}$ & $45.24 \pm 42.08 \mathrm{ab}$ & $74.16 \pm 31.49 \mathrm{a}$ & $24230 \pm 4415.89 \mathrm{ab}$ & $158 \pm 43.66 \mathrm{a}$ \\
$60 \mathrm{~m}$ & $52.61 \pm 9.75 \mathrm{a}$ & $40.82 \pm 9.13 \mathrm{a}$ & $24.23 \pm 5.84 \mathrm{a}$ & $50.32 \pm 8.61 \mathrm{a}$ & $21840 \pm 3275.23 \mathrm{a}$ & $125 \pm 53.18 \mathrm{a}$ \\
\hline
\end{tabular}

Note: Values within the same column with a common letter do not differ significantly $(\mathrm{P}<0.01)$.

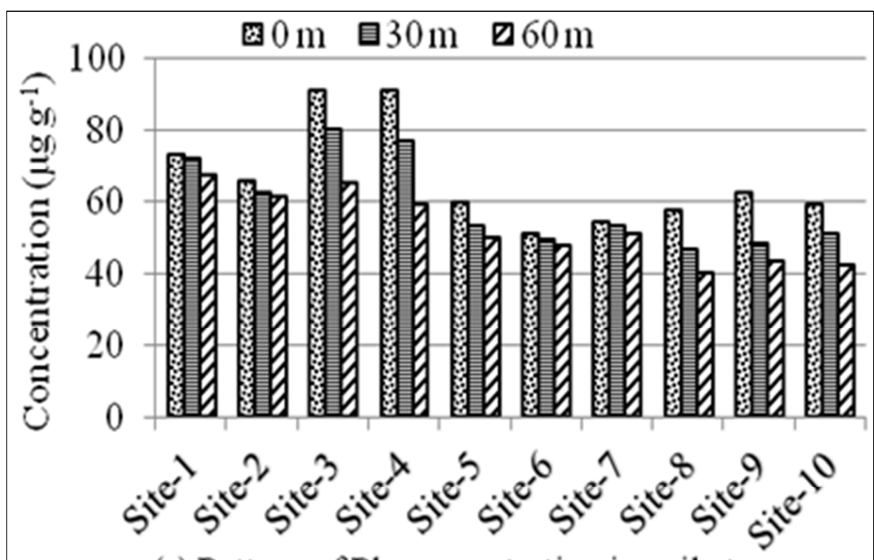

(a) Pattern of $\mathrm{Pb}$ concentration in soil at 0,30 and $60 \mathrm{~m}$ away from waste canal.
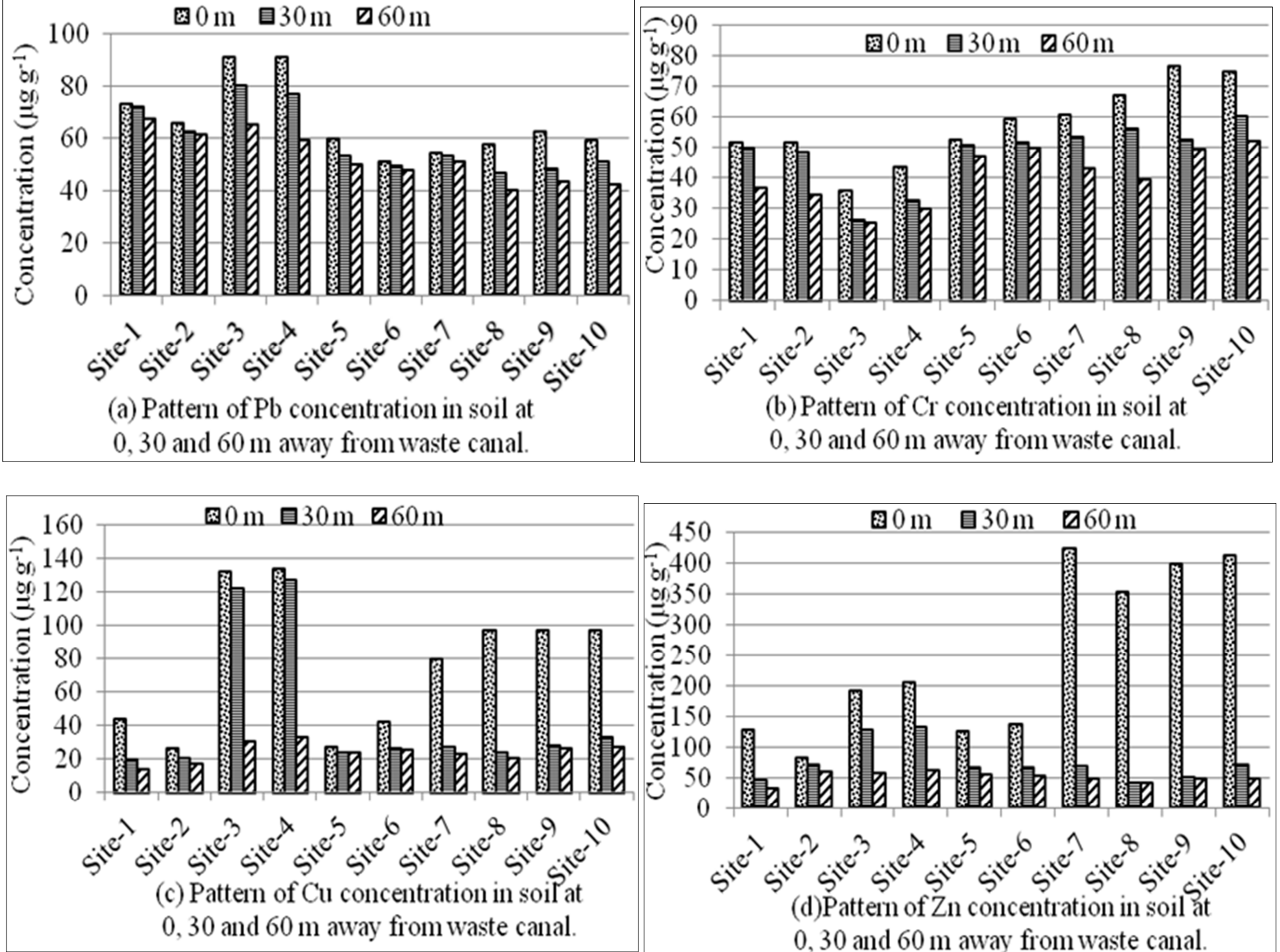

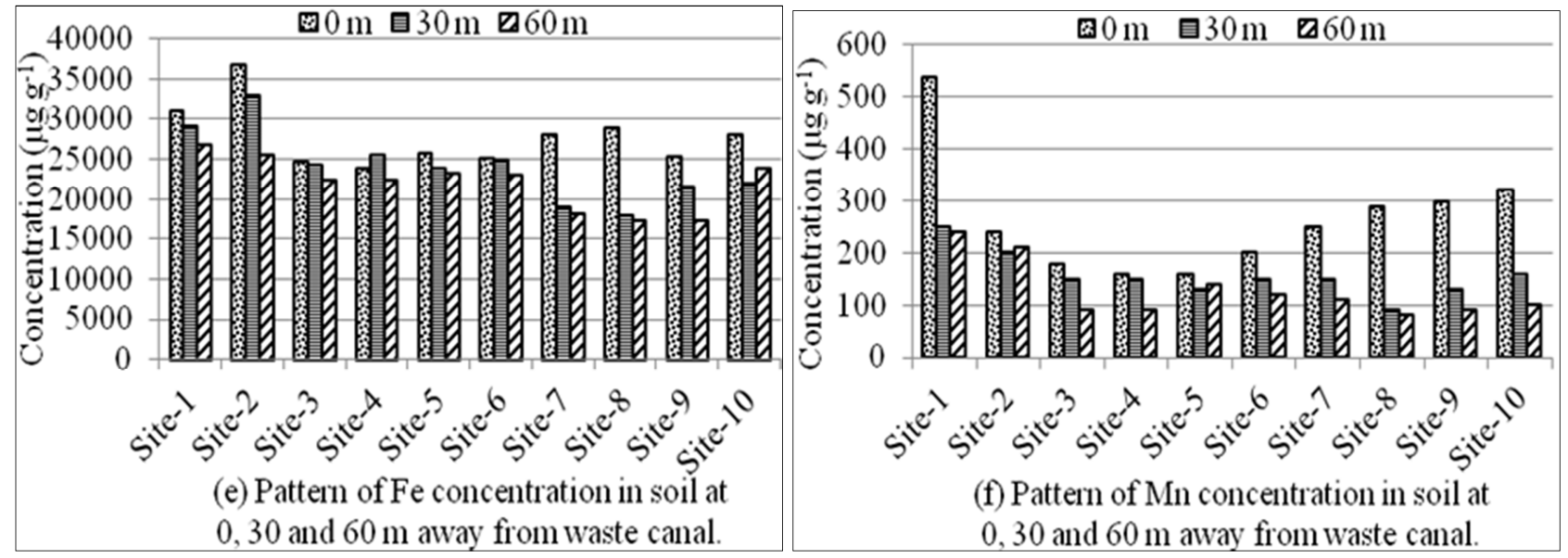

Fig. 2. Patterns of $\mathrm{Pb}(\mathrm{a}), \mathrm{Cr}(\mathrm{b}), \mathrm{Cu}(\mathrm{c}), \mathrm{Zn}(\mathrm{d}), \mathrm{Fe}(\mathrm{e})$ and $\mathrm{Mn}(\mathrm{f})$ concentration in soil at 0,30 and $60 \mathrm{~m}$ away from waste canal.

\subsection{Assessment of Pollution Level}

\subsubsection{Geoaccumulation Index ( $\left.I_{\text {geo }}\right)$}

$I_{\text {geo }}$ introduced by Muller [15] was used to assess heavy metal pollution in soils at seven grades (Table 3 ) at different distances from waste canals of Bhaluka Upazila. The calculated $\mathrm{I}_{\text {geo }}$ for heavy metals of soils at 0,30 and $60 \mathrm{~m}$ distances from waste canals of Bhaluka Upazila, and their corresponding contamination intensity are illustrated in Fig. $3 \mathrm{a}, 3 \mathrm{~b}$ and $3 \mathrm{c}$. Out of 10 sampling sites, 5 sites within $0 \mathrm{~m}$ distance from waste canal exhibited $\mathrm{I}_{\text {geo }}$ class 2 , indicating moderately contaminated soil quality for $\mathrm{Pb}$. Other samples exhibited $\mathrm{I}_{\text {geo }}$ class $1 \mathrm{for} \mathrm{Pb}$, indicating uncontaminated to moderately polluted soil quality. The $\mathrm{I}_{\mathrm{geo}}$ values for $\mathrm{Cr}$, $\mathrm{Fe}$ and $\mathrm{Mn}$ indicated unpolluted soil quality. However, 6 different samples for $\mathrm{Cu}$ and $\mathrm{Zn}$ exhibited uncontaminated to moderately contaminated soil quality and other samples had negative values for these elements. Four samples at $0 \mathrm{~m}$ and 3 samples at $60 \mathrm{~m}$ distance for $\mathrm{Pb}$ were exhibited moderately polluted soil quality. Soils at 5-1000 m distances from the both roadsides of Xi'an-Baoji Highway, China also revealed unpolluted to moderately polluted soil quality for $\mathrm{Pb}, \mathrm{Cu}$ and $\mathrm{Zn}[35]$.

Table 3. Measure of pollution in soil by using Geoaccumulation index (Igeo) (Muller, 1969).

\begin{tabular}{lll}
\hline $\begin{array}{l}\text { Geoaccumulatio } \\
\text { n Index }\end{array}$ & Igeo $_{\text {Class }}$ & Designation of soil or sediment quality \\
\hline $10-5$ & 6 & Extremely polluted \\
$4-5$ & 5 & Strongly/ extremely polluted \\
$3-4$ & 4 & Strongly polluted \\
$2-3$ & 3 & Moderately/ strongly polluted \\
$1-2$ & 2 & Moderately polluted \\
$0-1$ & 1 & Uncontaminated/moderately polluted \\
0 & 0 & Unpolluted \\
\hline
\end{tabular}

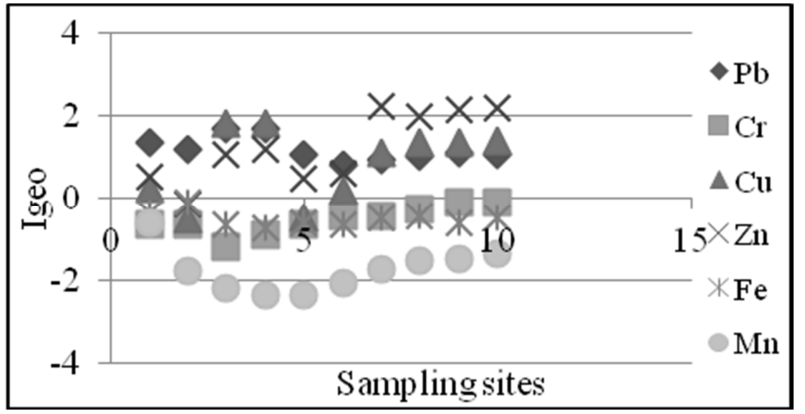

(a) Geoaccumulation index $\left(\mathrm{I}_{\text {geo }}\right)$ of heavy metals in soil samples at $0 \mathrm{~m}$ distance.

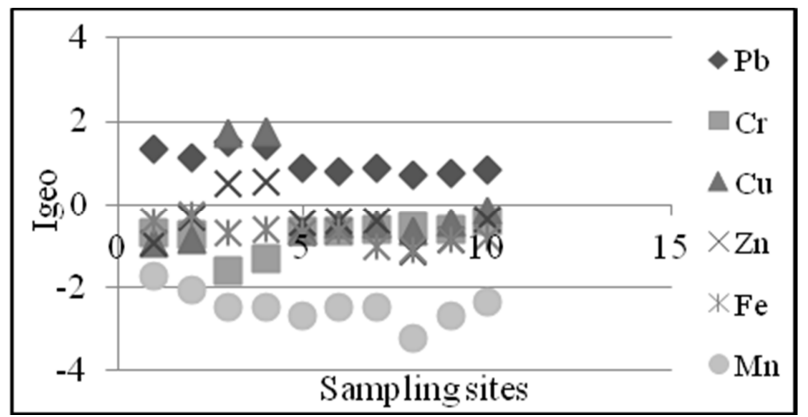

(b) Geoaccumulation index ( $\left.\mathrm{I}_{\text {geo }}\right)$ of heavy metals in soil samples at $30 \mathrm{~m}$ distance.

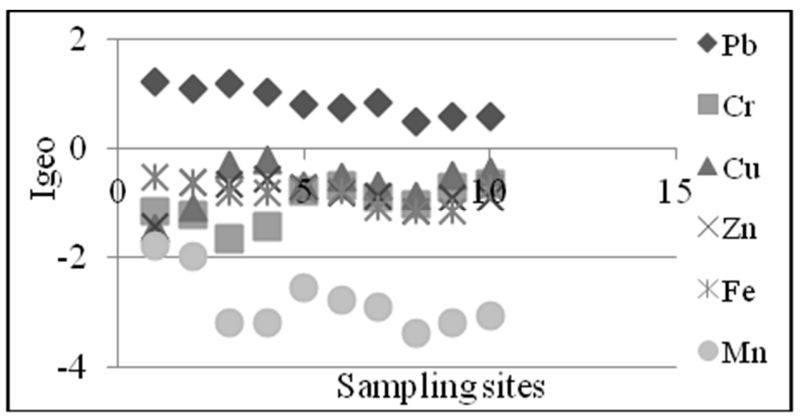

(c) Geoaccumulation index $\left(\mathrm{I}_{\mathrm{geo}}\right)$ of heavy metals in soil samples at $60 \mathrm{~m}$ distance.

Fig. 3. Geoaccumulation index (Igeo) of heavy metals in soil samples at $0(a)$, 30 (b) and $60 \mathrm{~m}$ (c) distance from waste discharging canal at Bhaluka Upazila. 


\subsubsection{Pollution Load Index (PLI)}

The highest PLI (2.61) was observed at Site-6 (Amtoli) indicates heavily contaminated site among others and ranges from 0.93 to 2.61 for all sites (Fig. 4) with a mean value of 1.50 for soil samples at $0 \mathrm{~m}$ distance from waste canal. At 30 $\mathrm{m}$ distance, the PLI values varied from 0.7 to 1.2 with a mean value of 0.8 which was 0.2 for the 3 rd distance having PLI ranging from 0.1 to 0.3 . The result showed gradual decreases of PLI values with the increased of sampling distance from the waste canal. Out of 10 sampling sites, 8 sites at $0 \mathrm{~m}$ and only 1 site at $30 \mathrm{~m}$ distance from waste canal had PLI values $>1.0$, indicates contaminated. Fan [35] also observed moderate pollution level of soils at 5-1000 m distances from the both roadsides of Xi'an-Baoji Highway, China, as per PLI values. The PLI can provide some understanding to the public of the area about the quality of soils of their environment and it can indicate the trends over time and area. In addition, it also provides valuable information and advice for the policy and decision makers about the pollution level of the area [36].

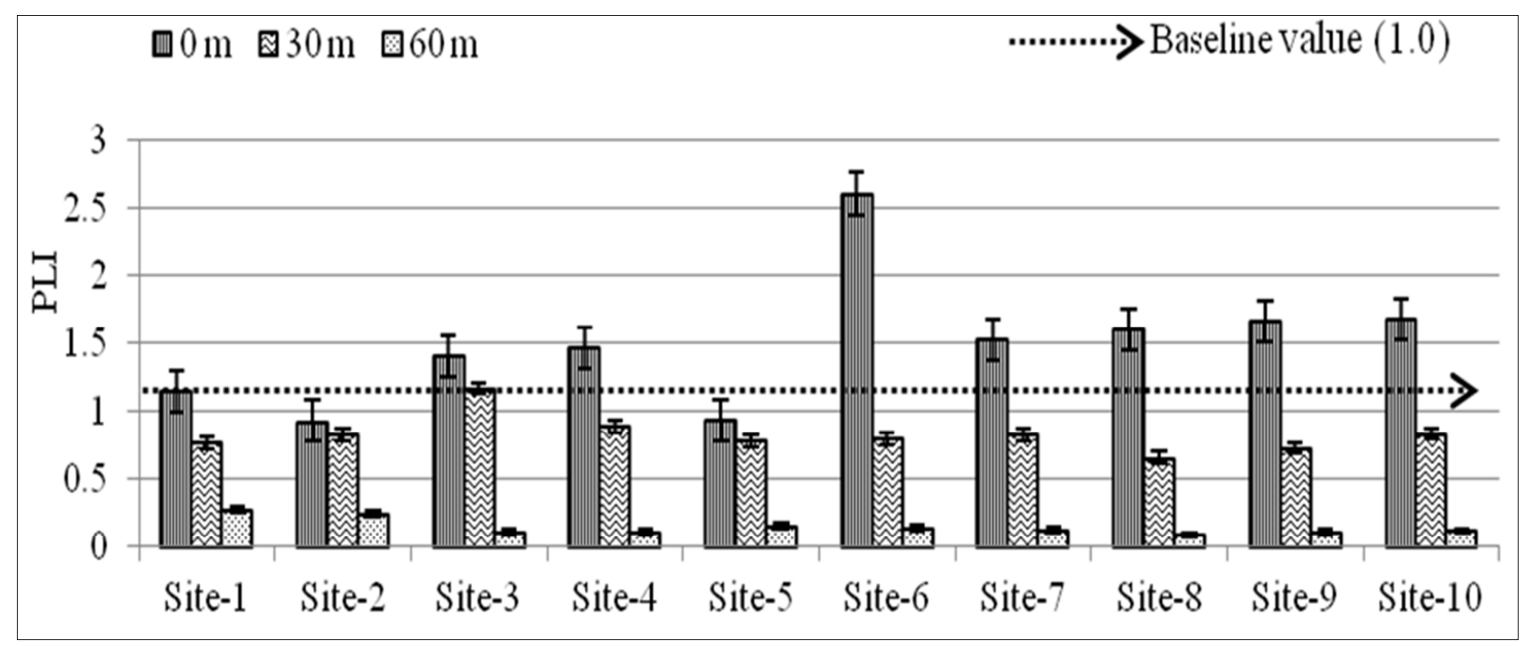

Fig. 4. Pollution Load Index (PLI) of soil samples at 0, 30 and $60 \mathrm{~m}$ distances from waste canal. Vertical bars denote the standard error.

\subsubsection{Contamination Factor (CF)}

The contamination factor and degree of contamination are used to determine the contamination status of soils or sediments of an area. In this study, CF was calculated according to Tomlinson et al. [17]. CF in soil samples varied from 2.0 to 4.6, 0.3 to 0.9, 0.3 to 3.0, 0.4 to $4.4,0.4$ to 0.8 and 0.1 to 0.6 for $\mathrm{Pb}, \mathrm{Cr}, \mathrm{Cu}, \mathrm{Zn}, \mathrm{Fe}$ and $\mathrm{Mn}$, respectively (Table 4). It is evident from Table 4 that the contamination factor for $\mathrm{Pb}, \mathrm{Cu}$ and $\mathrm{Zn}$ was higher, which indicates that $\mathrm{Pb}, \mathrm{Cu}$ and $\mathrm{Zn}$ were the major pollutants in these soils giving rise to PLI values for the study area.

Table 4. The contamination factor (CF) for heavy metals at different sampling sites of Bhaluka Upazila.

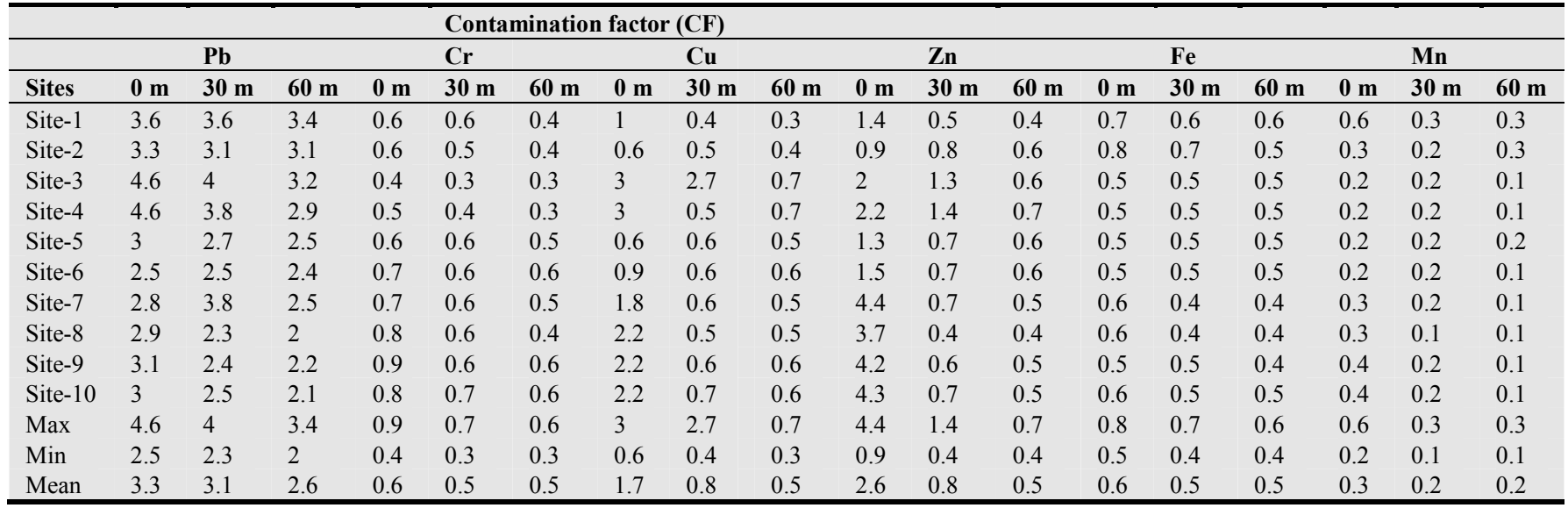

\subsubsection{Enrichment Factor (EFc)}

Sutherland [37] has distinguished five classes of enrichment factors: $\mathrm{EFc}<2$ shows deficiency to low enrichment, $2<\mathrm{EFc}<5$ shows moderate enrichment, $5<\mathrm{EFc}$ $<20$ shows significant enrichment, $20<\mathrm{EFc}<40$ shows very high enrichment, and FFc $>40$ shows extremely high enrichment. Based on this classification, the sampling sites were moderate to significant enrichment for $\mathrm{Pb}, \mathrm{Cu}$, and $\mathrm{Zn}$ and low enrichment for $\mathrm{Mn}$ and $\mathrm{Cr}$ at 0-60 m distances (Fig. $5 \mathrm{a}, 5 \mathrm{~b}$ and 5c). The highest EFc value (14.63) was observed at Bagrapara (Site-9) for Zn. Rafiei et al. [25] also reported an elevated level of enrichment factor for heavy metals in Dashkasan gold mine soils of Iran. Measuring enrichment 
factor $(\mathrm{EFc})$ is an essential part of geochemical studies and is generally used to differentiate between the metals originating from anthropogenic (non-crustal) and geogenic (crustal) sources, and to assess the degree of metal contamination [38, $39,40]$. It is presumed that high EFc values indicate an anthropogenic source of metals, mainly from activities such as industrialization, urbanization, deposition of industrial wastes and others. Since, the bioavailability and toxicity of any metal in soils and sediments depends upon the chemical form and concentration of the metal [41], it can be inferred that metals in soil and sediment samples with the high $\mathrm{EFc}$ values like $\mathrm{Pb}$, $\mathrm{Cu}$ and $\mathrm{Zn}$ have a potential for mobility and bioavailability in the ecosystems and associated health risk.

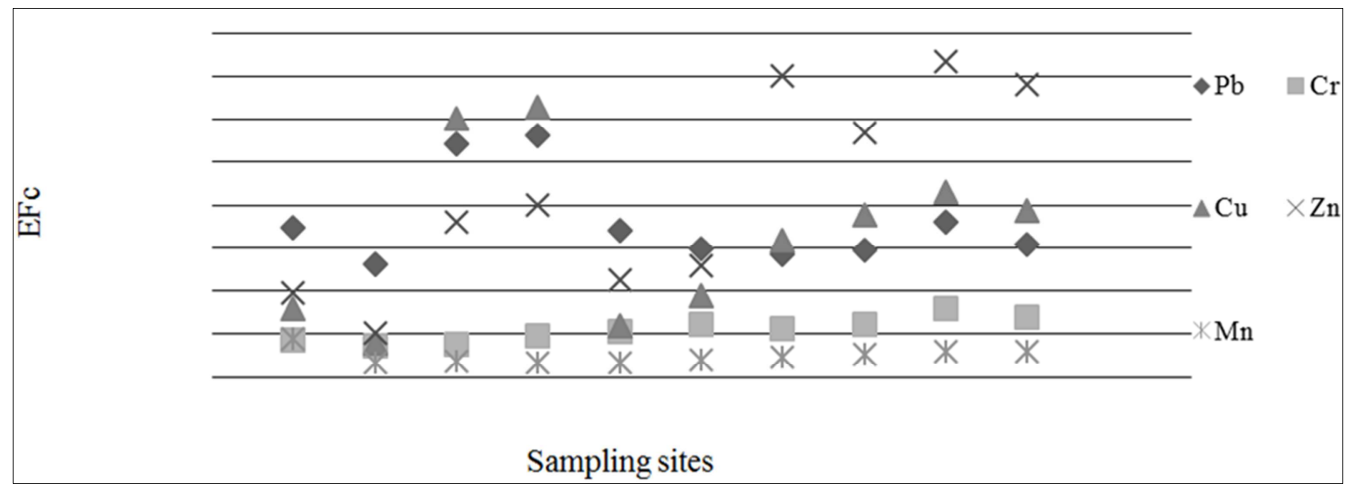

(a) EFc values of metals in soil samples at $0 \mathrm{~m}$ distance.

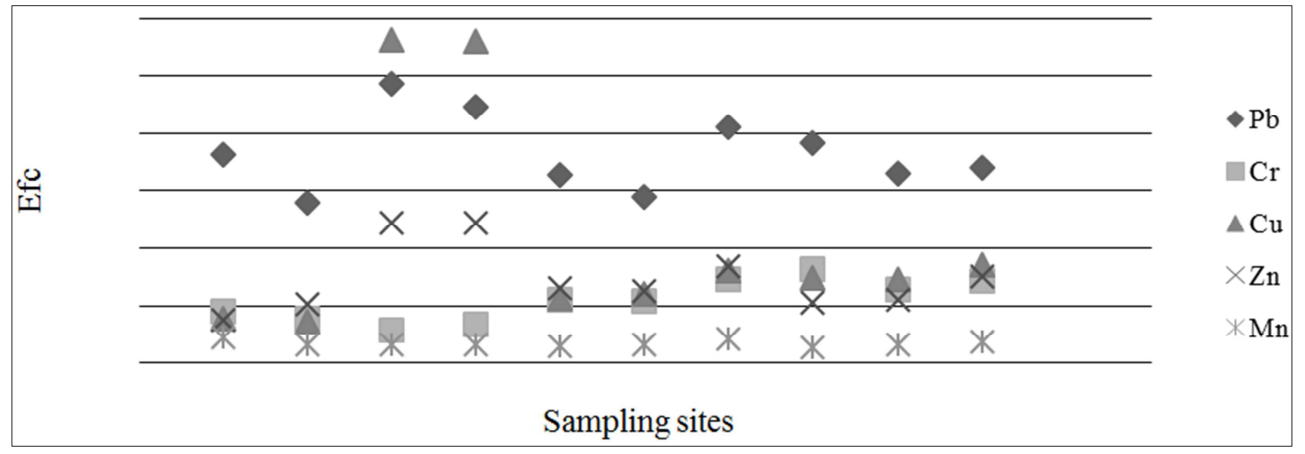

(b) EFc values of metals in soil samples at $30 \mathrm{~m}$ distance.

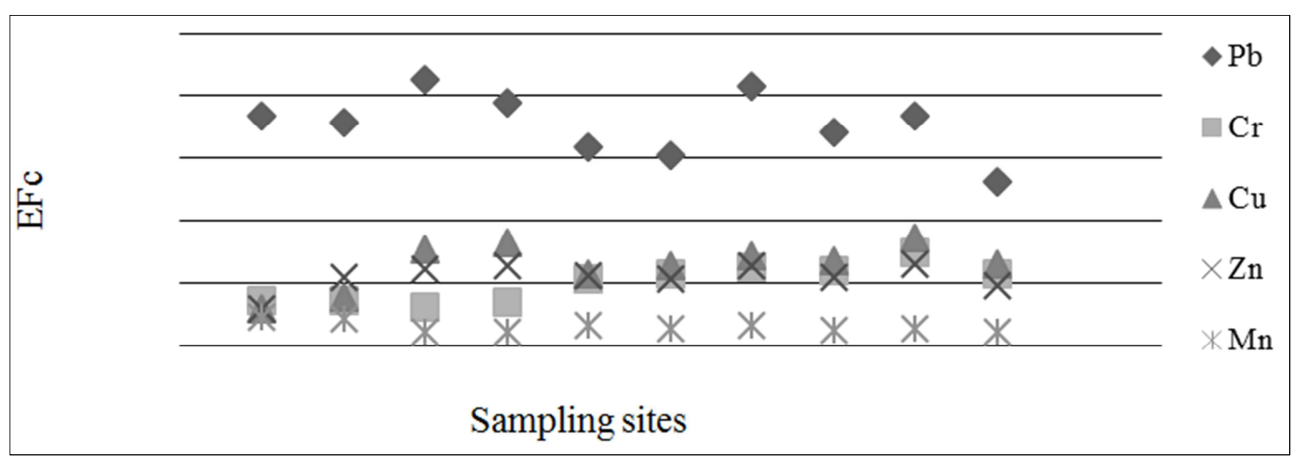

(c) EFc values of metals in soil samples at $60 \mathrm{~m}$ distance.

Fig. 5. EFc values of metals in soil samples at 0 (a), 30 (b) and $60 \mathrm{~m}$ (c) distances from waste canals at Bhaluka Upazila.

\section{Conclusions}

This study showed that the intensive uncontrolled operation of various industries has resulted in the release of heavy metals in the local environment and causes elevated concentrations in the surrounding soil. The levels of heavy metals in soils were found to decrease with the increase of distance from waste discharging canal. $\mathrm{Pb}$ levels at 0,30 and $60 \mathrm{~m}, \mathrm{Cu}$ and $\mathrm{Zn}$ at $0 \mathrm{~m}$ distance crossed the average shale value indicating heavy metal pollution. The study area was contaminated with $\mathrm{Pb}, \mathrm{Cu}$ and $\mathrm{Zn}$ (upto 90.93, 133.85 and $422.10 \mu \mathrm{g} \mathrm{g}^{-1}$, respectively) as per different ecological indicators calculation like $\mathrm{I}_{\text {geo }}$, PLI and EFc. Higher $\mathrm{I}_{\text {geo }}$, PLI and EFc values indicates that industrial effluents were the main causes of heavy metal pollution in soil of Bhaluka Upazila. It can be concluded that, soil quality heavily deteriorates continuously with time and spacing, and this may have adverse effects on human health through food chain contamination and ecosystem. 


\section{References}

[1] Karim, Z., Qureshi, B. A., Mumtaz, M., Qureshi, S. (2014), "Heavy metal co ntent in urban soils as an indicator of anthropogenic and natural influences on landscape of Karachi-amultivariate spatio-temporal analysis", Ecol. Indic., $42,20-31$.

[2] Islam, M. S., Ahmed, M. K., Al-Mamun, M. H., Masunaga, S. (2015), "Potential ecological risk of hazardous elements in different land-use urban soils of Bangladesh", Sci. Total Environ., 512-513: 94-102.

[3] DOE (Department of Environment). (2001), "Bangladesh: State of Environment", Ministry of Environment and Forest. Pub. UNEP., 1-74.

[4] Ahmed, G., Miah, M. A., Anawar, H. M., Chowdhury, D. A., Ahmad, J. U. (2011), "Influence of multi-industrial activities on trace metal contamination: an approach towards surface water body in the vicinity of Dhaka Export Processing Zone (DEPZ)", Environ. Monitoring Assessment, 2 (1), 1-10.

[5] Azom, M. R., Mahmud K., Yahya S. M., Sontu A., Himon S. B. (2012) "Environmental impact assessment of tanneries: a case study of Hazaribag in Bangladesh", Int. J. Environ. Sci. Develop., 3 (2), 152-156.

[6] Islam, M. S., Ahmed, M. K., Al-Mamun, M. H., Masunaga, S. (2014a), "Trace metals in soil and vegetables and associated health risk assessment”, Environ. Monit. Assess., 186, 8727-8739.

[7] Gisbert, C., Ros, R., DeHaro, A., Walker, D. J., Pilar-Bernal, M., Serrano, R., Avino, J. N. (2003), "A plant genetically modified that accumulates $\mathrm{Pb}$ is especially promising for phytoremediation", Biochem. Biophysical Res. Commun., 303, 440-445.

[8] Qingren, W., Dong, Y., Wi, Y., Liu, X., Wang, D. (2001), "Instances of soil and crop heavy metal contamination in China”, Soil Sediment Contamin., 10 (5), 497-510.

[9] Islam, M. S., Ahmed, M. K., Al-Mamun, M. H. (2014b), "Heavy metals incereals and pulses: health implications in Bangladesh", J. Agric. Food Chem., 62: 10828-10835.

[10] Richards, L. A. (1969), "Diagnosis and improvement of saline and alkali soils", US salinity laboratory staff. agricultural handbook. No.60.USDA.USA.

[11] Page, A. L., Miller, R. H., Keeney, D. R. (1982), "Methods of soil analysis", Part-2. Chemical and microbiological properties. $2^{\text {nd }}$ edn. Soil science society of American Inc. Madison, Wisconsin, USA. pp. 403-430.

[12] Tam, N. F. Y., Yao, M. W. Y. (1999), “Three digestion methods to determine concentrations of $\mathrm{Cu}, \mathrm{Zn}, \mathrm{Cd}, \mathrm{Ni}, \mathrm{Pb}, \mathrm{Cr}, \mathrm{Mn}$ and $\mathrm{Fe}$ in mangrove sediments from Sai Keng, Chek Keng and Sha Tau Kok, Hong Kong”, Bull. Env. Contam. Toxicol., 62, 708-716.

[13] Sparks DI (Editor) (1996), "Methods of soil analysis", Part III, Chemical methods. SSSA book series No.5, Soil science society of America. American society of agronomy, Inc. Madison, USA.

[14] Singh, D., Chhonkar, P. K., Pandey, R. N. (1999), "Soil plant water analysis", A method manual. IARI, New Delhi, India.
[15] Muller, G. (1969), "Index of Geoaccumulation in sediments of the Rhine river", Geojournal, 2 (3), 108-118.

[16] Turekian, K. K., Wedepohl, K. H. (1961), "Distribution of the elements in some major units of the earth's crust", Geological Soc. American Bull., 72, 175-192.

[17] Tomlinson, D. C., Wilson, J. G., Harris, C. R., Jeffrey, D. W. (1980), "Problems in the assessment of heavy metal levels in estuaries and the formation of a pollution index", Helgoland Marine Res., 33, 566-575.

[18] Angula, E. (1966), “The Tomlinson Pollution Index applied to heavy metal, Mussel-Watch data: A useful index to assess coastal pollution", Sci. Total Environ., 187, 19-56. http://dx.doi.org/10.1016/0048-9697(96)05128-5

[19] Huheey, J. E. (1983), "Inorganic Chemistry: Principles of Structure and Reactivity", Harper and Row Publishers, New York, 912.

[20] Loska, K., Cebula, J., Pelczar, J., Wiechula, D., Kwapulinski, J. (1997), "Use of enrichment and contamination factors together with geoaccumulation indexes to evaluate the content of $\mathrm{Cd}$, $\mathrm{Cu}$ and $\mathrm{Ni}$ in the Rybnik water reservoir in Poland", Water Air Soil Poll., 93, 347-365.

[21] Atgin, R. S., El-Agha, O., Zararsiz, A., Kocatas, A., Parlak, H., Tuncel, G. (2000), "Investigation of the sediment pollution in Izmir Bay: trace elements", Spectrochimica Acta-Part B, 55(7), 1151-1164.

[22] Sultana, M. S., Kulsum, U., Shakila, A., Islam, M. S. (2012), "Toxic metal contamination on the river near industrial area of Dhaka", Univer. J. Environ. Res. Technol., 2 (2), 56-64.

[23] Kabata-Pendias, A., Pendias, H. (1992), "Trace Elements in Soils and Plants", $2^{\text {nd }}$ ed., CRC Press, London.

[24] Naser, H. M., Sultana, S., Gomes, R., Noor, S. (2012), "Heavy metal pollution of soil and vegetable grown near roadside at Gazipur", Bangladesh J. Agric. Res., 37 (1), 9-17.

[25] Rafiei, B., Bakhtiari Nejad, M., Hashemi, M. and Khodaei, A. S. (2010), "Distribution of heavy metals around the Dashkasan Au mine", Int. J. Environ. Res., 4(4), 647-654.

[26] Ahmed, F., Katita, M., Sattar, M. A., Ishiga, H., Rahman, M. M., Bibi, M. H. (2004), "Arsenic and other thirteen heavy metal contamination of Madhupur tract soil layers", Bangladesh $J$. Environ. Sci., 9, 151-156.

[27] Addo, M. A., Darko, E. O., Gordon, C., Nyarko, B. J. B., Gbadago, J. K., Nyarko, E., Affum, H. A. and Botwe, B. O. (2012), "Evaluation of heavy metals contamination of soil and vegetation in the vicinity of a cement factory in the Volta region, Ghana", International Journal of Science and Technology, 2(1), 40-50.

[28] Ahmed, A. M. M., Salah, M. A. H. and Ahmed, F. E. A. (2011), Assessment of the Heavy Metals around two Municipal Solid Waste (MSW) Dumpsites, Egypt, ECO Services International, March.

[29] Al-Oud, S. S., Nadeem, M. E. A., Al-Shbel, B. H. (2011), "Distribution of heavy metals in soils and plants around a cement factory in Riyadh City, Central Saudi Arabia", American-Eurasian J. Agric. Environ. Sci., 11(2), 183-191.

[30] USEPA (U. S. Environmental Protection Agency). (1999), "Screening level ecological risk assessment protocol for hazardous waste combustion facilities", Vol. 3, Appendix E: Toxicity reference values. EPA 530-D99- 001C. 
[31] Sakawi, Z., Ariffin, M. R., Mastura, S. A. S. and Jali, M. F. M. (2013), "The analysis of heavy metal concentration per distance and depth around the vicinity of open landfill", Research Journal of Applied Sciences, Engineering and Technology, 5 (24), 5619-5625.

[32] Allaway, W. H. (1968), "Agronomic control over the environmental cycling of trace elements", Advan. Agronomy, $20,235-274$.

[33] Tahar, K., Keltoum, B. (2011), "Effects of heavy metals pollution in soil and plant in the industrial area, West Algeria", J. Korean Chem. Soc., 55 (6), 1018-1023.

[34] Tiwari, M. K., Samir Bajpai, S. and Dewangan, U. K. (2015), "An analytical study of heavy metal concentration in soil of an industrial region of Chhattisgarh, central India", International Journal of Scientific and Research Publications, 5 (7), 1-8.

[35] Fan, S. (2014), "Assessment of spatial distribution and pollution with heavy metals in roadside soils along Xi'an-baoji highway in northwest China”, Environmental Engineering and Management Journal, 13(12), 3161-3171.

[36] Suresh G., Sutharsan P., Ramasamy V. (2012), “Assessment of spatial distribution and potential ecological risk of the heavy metals in relation to granulometric contents of Veeranam lake sediments, India”, Ecotoxicol. Env. Safety, 84, 117-124.

[37] Sutherland, R. A. (2000), "Bed sediment-associated trace metals in an urban stream, Oahu, Hawaii", Environ. Geol., 39, 611-627.

[38] Selvaraj, K., Moha, V. R. Szefer, P. (2004). Evaluation of metal contamination in coastal sediments of the Bay of Bengal, India: geochemical and statistical approaches. Mar. Pollut. Bull, 49, 174-185.

[39] Olivares-Rieumont, S., Rosa, D. D. L, Lima, L., Graham, D. W., Alessandro, K. D., Borroto, J., Martinez, F. \& Sanchez, J. (2005). Assessment of heavy metal levels in Almendared River sediments-Havana City, Cuba. Water Res, 39, 3945-3953.

[40] Yongming, H., Peixuan, D., Junji, C. \& Posmentier, E. S. (2006). Multivariate analysis of heavy metal contamination in urban dusts of Xi'an, Central China. Sci. Total Environ, 355, 176-186.

[41] Kwon, C. H., Zhu, X., Zhang, J., Knoop, L. L., Tharp, R., Smeyne, R. J., Eberhart, C. G., Burger, P. C., Baker, S. J. (2001), "Pten regulates neuronal soma size: a mouse model of Lhermitte-Duclos disease", Nature Genetics, 29, 404-411. 